\title{
Impact of Nitrate and Ammonium ratio on Nutrition and Growth of two Epiphytic Orchids
}

\author{
CIBELE MANTOVANI, RENATO M. PRADO and KATHIA F.L. PIVETTA
}

Faculdade de Ciências Agrárias e Veterinárias, Universidade Estadual Paulista "Júlio de Mesquita Filho"/UNESP, Via de Acesso Prof. Dr. Paulo Donato Castellane, s/n, Zona Rural, 14884-900 Jaboticabal, SP, Brazil

Manuscript received on December 19, 2017; accepted for publication on March 2, 2018

\begin{abstract}
Phalaenopsis and Dendrobium do not grow and flower well with $100 \%$ ammonium $\left(\mathrm{NH}_{4}-\mathrm{N}\right)$; and there are detailed studies on the effects of nitrate $\left(\mathrm{NO}_{3}-\mathrm{N}\right)$ and ammonium ratios on the flowering, but no information about accumulation of other nutrients and the effects of ammonium toxicity on orchids. For this reason, two experiments were carried out with orchids: Phalaenopsis 'Golden Peoker' and Dendrobium 'Valentine'. Six months after acclimatization the plants were transplanted to individual plastic vessels and the treatments consisted of five ratios (\%) of nitrate / ammonium (0/100, 25/75, 50/50,75/25, 100/0). The sources of $\mathrm{NO}_{3}-\mathrm{N}$ and $\mathrm{NH}_{4}-\mathrm{N}$ were calcium nitrate and ammonium sulfate, respectively. After 12 months treatment, when the plants were beginning to issuance of flower stem, the accumulation of: $\mathrm{N}, \mathrm{P}, \mathrm{K}, \mathrm{Ca}$ and $\mathrm{Mg}$ in the shoot and biometric variables were evaluated for both species. $\mathrm{The}_{4} \mathrm{NH}_{4} \mathrm{~N}$ ratio of $40 \%$ and $50 \%$ of the total nitrogen benefited the growth of Phalaenopsis and Dendrobium, respectively. The application of higher proportions of ammonium resulted in decreased $\mathrm{N}, \mathrm{K}, \mathrm{Ca}$ and $\mathrm{Mg}$ absorption, index of green color and increased leakage of electrolytes in Phalaenopsis and Dendrobium. $\mathrm{NH}_{4}-\mathrm{N}$ proportions greater than $75 \%$ for 12 months caused toxicity in Phalaenopsis and Dendrobium.
\end{abstract}

Key words: nutritional status, fertigation, Orchidaceae, ammonium toxicity.

\section{INTRODUCTION}

Nitrogen fertilization is an essential practice for the cultivation of orchids. Among the various forms, such as $\mathrm{NO}_{3}-\mathrm{N}, \mathrm{NH}_{4}-\mathrm{N}$ and urea, the $\mathrm{NO}_{3}-\mathrm{N}$ is the best form of $\mathrm{N}$ absorbed by orchids (Wang and Chang 2017).

The beneficial effect of $\mathrm{NH}_{4}-\mathrm{N}$ is due to the lower energy consumption, compared with $\mathrm{NO}_{3}-\mathrm{N}$, due to ammonium direct incorporation into the carbon chain in the assimilation of $\mathrm{N}$, without the need for reduction phases by enzymatic action

Correspondence to: Cibele Mantovani

E-mail: orquidariomantovani@gmail.com
(Bittsánszky et al. 2015), and may increase N utilization efficiency (Sarasketa et al. 2014).

However, when the ammonium application is the only source of $\mathrm{N}$ it may result in physiological and morphological disturbances leading to decrease plant growth and $\mathrm{N}$ toxicity (Esteban et al. 2016).

Additionally, high application amounts of ammonium inhibits cation uptake $\left(\mathrm{K}^{+}, \mathrm{Ca}^{+}\right.$and $\mathrm{Mg}^{+}$), increases oxidative stress and requires high energy costs to maintain low levels of $\mathrm{NH}_{4}^{+}$in cytosolic content (Britto and Kronzucker 2002, Bittsánszky et al. 2015), causes changes in root architecture and causes chlorosis in the leaves 
resulting in decrease in plant growth. There are no studies reporting the effects of ammonium toxicity on orchids.

There are differences between varieties with respect to their response to ammonium (Cruz et al. 2011) and nitrate (Huang et al. 2013) even through they are of the same species.

The balance between the ratios $\mathrm{NO}_{3}-\mathrm{N} /$ $\mathrm{NH}_{4}-\mathrm{N}$ in the nutrient solution for growth of the Phalaenopsis orchid was determined by Wang (2008). When $0.221 \mathrm{~g} \mathrm{~L}^{-1}$ of $\mathrm{N}$ via fertigation was applied to Phalaenopsis Blume x Taisuco Kochdian growth was reduced with excessive supply of ammoniacal $\mathrm{N}$ and the best growth occurred with the application of $75 \%$ of the $\mathrm{N}$ in the form of $\mathrm{NO}_{3}-\mathrm{N}$ and $25 \%$ in the form of $\mathrm{NH}_{4}-\mathrm{N}$. However, this study did not evaluate nutrient accumulation and ammonium toxicity, and the plants were cultivated for eight months without the supply of micronutrients.

The pattern of uptake of ammonium and nitrate varies according to the carbon source supplied, $\mathrm{pH}$ of the nutrient medium and its concentration. Dendrobium Multico White tissues grown in liquid culture media showed a preferential uptake of ammonium ions over nitrate (Hew and Yong 2004).

Ruamrungsri et al. (2014) cultivated Dendrobium Sonia 'Ear Sakul' plants with different $\mathrm{NH}_{4}-\mathrm{N}$ : $\mathrm{NO}_{3}-\mathrm{N}$ ratios $(0: 0,0: 200$, 50:150 and 100:100 $\mathrm{mg} \mathrm{L}^{-1}$ of $\left.\mathrm{N}\right)$ once a week and the results showed that presence of $\mathrm{NO}_{3}-\mathrm{N}$ in the solution increased the absorption of $\mathrm{NH}_{4}-\mathrm{N}$; they recommended to supply $\mathrm{N}$-fertilizer in the combination of $\mathrm{NH}_{4}-\mathrm{N}: \mathrm{NO}_{3}-\mathrm{N}$ via leaves to stimulate growth and the uptake of ions into plant organs for assimilation. However, the nutritional status of the plants in relation to the other nutrients and the ammonium toxicity were not considered.

Therefore the aim of this work was to determine the effects of ratios of $\mathrm{NO}_{3}-\mathrm{N}$ and $\mathrm{NH}_{4}-\mathrm{N}$ on the accumulation of $\mathrm{N}, \mathrm{K}, \mathrm{Ca}$ and $\mathrm{Mg}$ in the shoot and the effects of ammonium toxicity on growth of Phalaenopsis Golden Peoker and Dendrobium Valentine.

\section{MATERIALS AND METHODS}

The experiment was carried out in an orchid greenhouse located in Itapolis, São Paulo, Brazil. The orchid seedlings used, Phalaenopsis 'Golden Peoker' and Dendrobium 'Valentine', were obtained via in vitro propagation, acclimatized in plastic trays with dry Sphagnum moss substrate, and received the complete nutrient solution of Sarruge (1975) via fertigation every two weeks.

The plants were kept in a greenhouse with average PPF of $300 \mathrm{mmol} \mathrm{m} \mathrm{m}^{-2}$ at noon, and maximum and minimum temperatures of 34 and $15^{\circ} \mathrm{C}$, respectively. After six months, the seedlings were transplanted individually into black polyethylene vessels (upper diameter: $13 \mathrm{~cm}$, lower diameter: $8.4 \mathrm{~cm}$, height: $10.6 \mathrm{~cm}$ ) with 0.9 $\mathrm{L}$ volume.

The pots were filled with a layer of expanded clay at the bottom ( $25 \%$ of the total volume) and with a 2:1 (v/v) mixture of pinus bark and charcoal medium, and placed on hanging tables at a height of $0.65 \mathrm{~m}$. The position of the pots was randomly changed after each treatment application, every 15 d.

The plants were irrigated twice and three times a week in the winter and summer, respectively, with $100 \mathrm{~mL}$ of distilled water $(\mathrm{pH}=6.8)$ per pot.

The concentration of nitrogen used in the nutrient solution was $136 \mathrm{mg} \mathrm{L}^{-1}$ of $\mathrm{N}$, which promotes adequate growth of Phalaenopsis plants in Brazilian climatic conditions (Mantovani et al. 2015). The other nutrient concentrations, in $\mathrm{mg} \mathrm{L}^{-1}$, in the nutrient solution used were: $31 \mathrm{P}, 234 \mathrm{~K}, 200$ $\mathrm{Ca}, 48 \mathrm{Mg}, 64 \mathrm{~S}, 0.5 \mathrm{~B}, 0.5 \mathrm{Mn}, 0.05 \mathrm{Zn}, 0.02 \mathrm{Cu}$, $0.01 \mathrm{Mo}, 5 \mathrm{Fe}$ (Sarruge 1975).

The calcium nitrate $\left(\mathrm{MW}=164 \mathrm{~g} \mathrm{~mol}^{-1}\right)$ was used as a source of $\mathrm{NO}_{3}-\mathrm{N}$, and ammonium sulfate 
$\left(\mathrm{MW}=132 \mathrm{~g} \mathrm{~mol}^{-1}\right)$ was used as the source of $\mathrm{NH}_{4}-\mathrm{N}$.

The treatments consisted of five proportions of $\mathrm{NH}_{4}^{+} / \mathrm{NO}_{3}^{-}(\%): 0 / 100,25 / 75 ; 50 / 50,75 / 25$, $100 / 0$. The experimental unit consisted of one plant per pot, eight plants were grown for each treatment, arranged in a completely randomized design.

The application of the nutrient solution of Sarruge (1975) with the source of nitrogen modified, according to the treatments was carried out via fertigation, once a week. The volume of solution applied per plant varied with the growth of the seedlings, approximately $50 \mathrm{ml}$ in the first six months and $90 \mathrm{ml}$ in the last six months of the experiment.

At each treatment, the $\mathrm{pH}$ of the solution was adjusted to 5.7 to 5.9 and it is noted that calcium concentrations were balanced with calcium chloride to maintain $0.29 \mathrm{~g} \mathrm{~L}^{-1}$ of $\mathrm{Ca}$ in all treatments.

After 12 months, when the plants were beginning to issuance of flower stem, evaluations were made: plant stem diameter ( $\mathrm{mm}$ ) measured at $2 \mathrm{~cm}$ from the base of the stem using a digital caliper (Starrett ${ }^{\circledR 727-2001 ~ m a n u f a c t u r e d ~ i n ~ I t u, ~ S a ̃ o ~}$ Paulo, BR); index of green color (with chlorophyll portable unit CCM-200 model OptiScience $\left.{ }^{\circledR}\right)$ and electrolyte leakage (Dionisio-Sese and Tobita 1998) in the central part of the adaxial surface of the last fully developed leaf of each plant).

The number of pseudobulbs and plant height (cm) were determined only for Dendrobium 'Valentine' while the number of leaves and plant width (corresponding to the distance between the apex of the last two fully expanded leaves, $\mathrm{cm}$ ) were measured only for Phalaenopsis 'Golden Peoker'.

The orchids were divided into aerial part/shoot and root and dried in forced circulation oven at 65 to $70^{\circ} \mathrm{C}$ temperature, until constant weight. The dry matter was determined and the plant material was ground to determine contents of $\mathrm{N}, \mathrm{K}, \mathrm{Ca}$ and $\mathrm{Mg}$ following the methodology described by Bataglia et al. (1983). Nutrient content and dry matter were used to calculate accumulation of $\mathrm{N}, \mathrm{K}, \mathrm{Ca}$ and $\mathrm{Mg}$ in the aerial shoot.

From these data, use efficiency of $\mathrm{N}=$ (total dry matter produced $)^{2} /$ (total content of $\mathrm{N}$ in the plant) (Siddiqi and Glass 1981) and absorption efficiency of $\mathrm{N}=$ (total content of $\mathrm{N}$ in plant) / (dry matter of roots) (Swiader et al. 1994) were calculated.

The results were analyzed by the F-test at $1 \%$ and 5\% probability; and when significant for proportions of $\mathrm{NH}_{4}^{+}$, polynomial regression studies and the means comparison test (Tukey at 5\% probability) were performed. The calculations were performed with the statistical program AgroEstat (Barbosa and Maldonado 2014).

\section{RESULTS}

The average accumulation of macronutrients in the aerial part of Phalaenopsis 'Golden Peoker' and in Dendrobium 'Valentine' followed the following increasing order of accumulation: $\mathrm{K}>\mathrm{Ca}>\mathrm{N}>$ $\mathrm{Mg}$ (Figure 1). There was an increase in quadratic form and then a decrease in the accumulation of these nutrients with the increase of ammonium proportions.

The increase of the ammonium concentration in the nutrient solution increased and then decreased the accumulation of total $\mathrm{N}$ reaching the maximum point in the ammonium proportion equal to $28 \%$ and $36 \%$ for Phalaenopsis and Dendrobium, respectively (Figure 1a).

It was observed that the balance of the ammonium proportion equal to $33 \%$ and $45 \%$, favored the absorption of $\mathrm{K}$ by Phalaenopsis and Dendrobium orchids, respectively (Figure 1b).

The increase of the ammonium concentration in the nutrient solution increased and then decreased the accumulation of $\mathrm{Ca}$ reaching the maximum point in the ratio of ammonium equal to $31 \%$ and $42 \%$ for Phalaenopsis and Dendrobium, respectively (Figure 1c). 

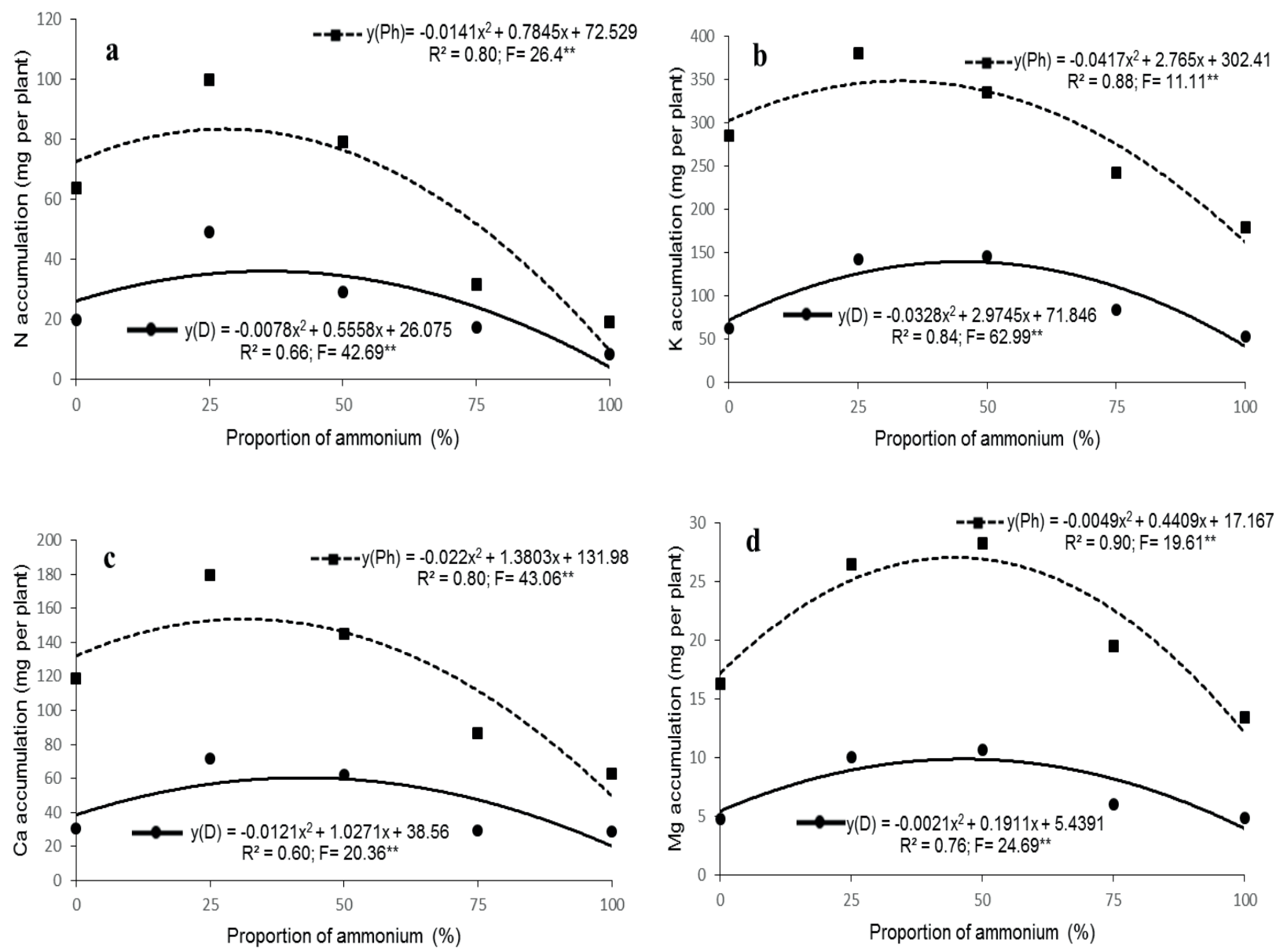

Figure 1 - Accumulation of N (a), K (b), Ca (c) and Mg (d) in aerial part of Phalaenopsis 'Golden Peoker' (Ph) and Dendrobium 'Valentine' (D) as a function of increasing proportions of ammonium in relation to nitrate after 12 months of the beginning of the application of the treatments. $* * \mathrm{p}<0.01$ by the $\mathrm{F}$ test.

Likewise, the maximum accumulation of $\mathrm{Mg}$ was reached with the proportions of ammonium equal to $45 \%$ and $46 \%$ for Phalaenopsis and Dendrobium, respectively (Figure 1d).

The absorption efficiency of $\mathrm{N}$ decreased linearly and the efficiency of $\mathrm{N}$ utilization presented a quadratic increment in Phalaenopsis reaching maximum point with the proportion of 38\% ammonium. In Dendrobium, the N absorption and utilization efficiency increased in a quadratic form with the increase of nitrate ratios, peaking at $38 \%$ and $65 \%$ ammonium respectively (Figure 2a and $2 b)$.

In Phalaenopsis the highest index of green color was with the proportion of $31 \%$ of ammonium; and in Dendrobium the highest index of green color were obtained for the proportion of $46 \%$ ammonium (Figure 2c).

The leakage of eletrolytes increased linearly with the increase of ammonium proportions in the two orchids studied (Figure 2d).

The increase of the ammonium concentration in the nutrient solution in Phalaenopsis (Figure 3) and in Dendrobium (Figure 4) promoted a quadratic increase in the vegetative variables studied until reaching the maximum point.

In Phalaenopsis the largest plant width (31 $\mathrm{cm}$ ) was calculated to be when the proportion was $41 \%$ ammonium; the largest stem diameter (15 $\mathrm{mm}$ ) with the proportion of $33 \%$ ammonium, the 

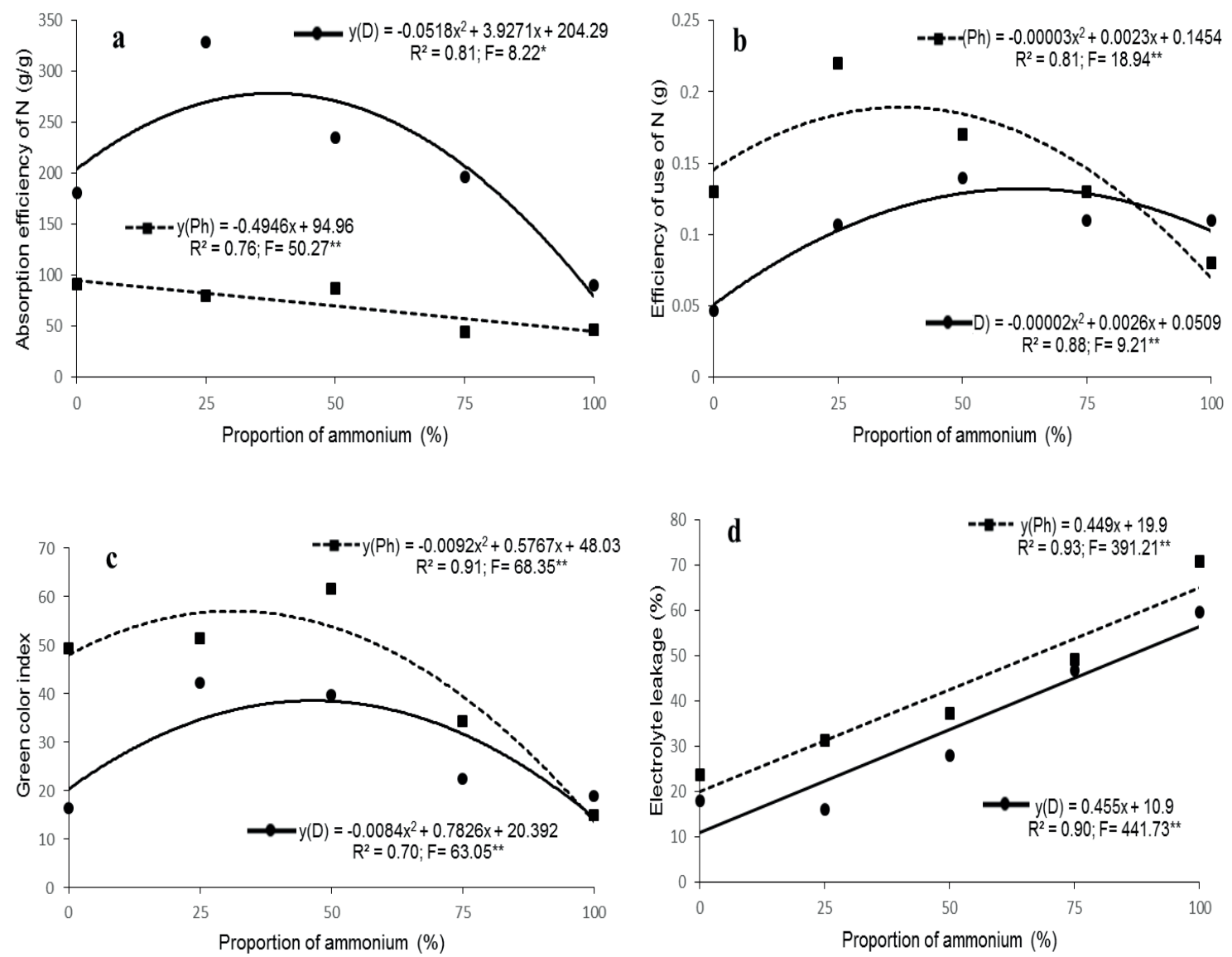

Figure 2 - Absorption efficiency of N (g / g) (a), use efficiency (g) (b), green color index (c) and electrolyte leakage from aerial part (\%) of (d) Phalaenopsis 'Golden Peoker' (Ph) and Dendrobium 'Valentine' (D) as a function of increasing proportions of ammonium (\%) in relation to nitrate, after 12 months of starting the treatments.* $\mathrm{p}<0.05$; ** $\mathrm{p}<0.01$ by the $\mathrm{F}$ test.

largest number of leaves (6) with the proportion of $36 \%$ ammonium and the highest dry matter (4.9 g) with a proportion of $35 \%$ of ammonium (Figure 3 ).

In Dendrobium Valentine, bigger plants (22 $\mathrm{cm})$, the largest diameter of the pseudobulb (9 $\mathrm{mm}$ ), the highest average number of pseudobulbs (3.6) and the largest dry matter (2.3 g) were grown with the proportion of $50 \%$ ammonium (Figure 4). Therefore, Dendrobium Valentine is more tolerant to ammonium as the source of $\mathrm{N}$ than Phalaenopsis Golden Peoker.

With the proportion of up to $57 \%$ of ammonium there was no toxicity in Phalaenopsis, whereas Dendrobium grew well with the proportion of ammonium up to $74 \%$, reinforcing the greater tolerance of this orchid genus to ammoniacal $\mathrm{N}$.

\section{DISCUSSION}

The two species of orchids fertilized with excess ammonium induced a decrease in the accumulation of cations, a fact also reported for $\mathrm{K}$ (Hoopen et al. 2010, Hess et al. 2006) and Ca (Siddiqi et al. 2002) in other cultivated plants.

This ionic imbalance occurs due to the increase of $\mathrm{NH}_{4}^{+}$influx and cation efflux across the plasma membrane, with extrusion of these cations to the cellular vacuole, which was confirmed with the increase of electrolyte leakage, which may cause 

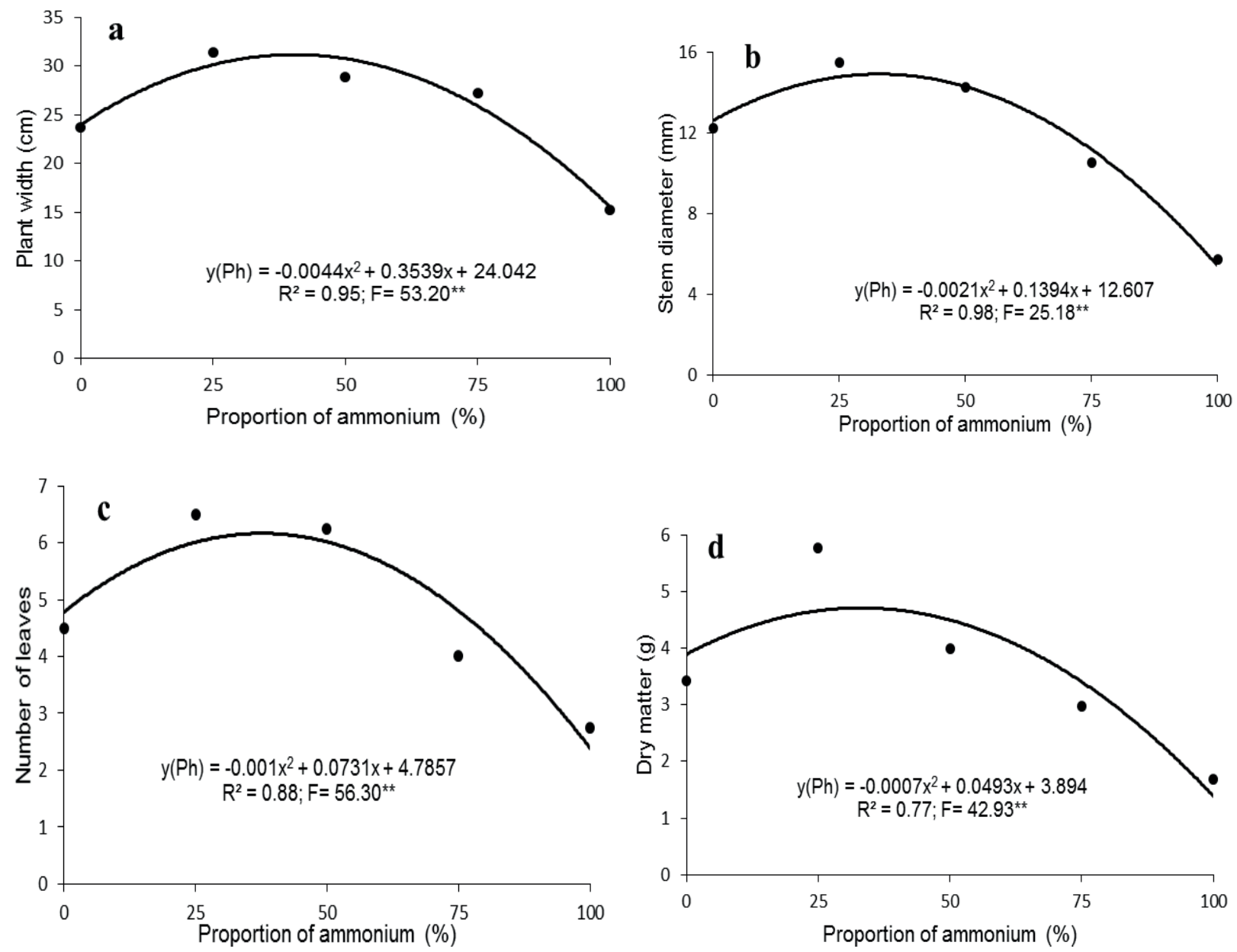

Figure 3 - Plant width (a), stem diameter (b), number of leaves (c), and total dry matter (d) of Phalaenopsis 'Golden Peoker' as a function of increasing proportions of ammonium (\%) in relation to nitrate, after 12 months from the beginning of the application of the treatments. ${ }^{* *} \mathrm{p}<0.01$ by the $\mathrm{F}$ test.

symptoms of nutritional deficiencies to the plants (Mendonza-Villarreal et al. 2015).

The excess of $\mathrm{NH}_{4}^{+}$caused a decrease in the efficiency of $\mathrm{N}$ uptake by the orchids probably due to the damage caused to the root system, which reflected in the accumulation of nutrients in the plant. Already decreased efficiency of utilization of $\mathrm{N}$ in the shoot was due to excess ammonium in the nutrient solution causing high accumulation of this cation in chloroplasts and can block the metabolism enzyme complex GS-GOGAT, responsible for the assimilation of $\mathrm{N}$ by plants (Bittsánszky et al. 2015).

It was observed that, for high ammonium proportions, the values of the green color index were lower, indicating damage in Phalaenopsis and Dendrobium due to excess of this cation. This was due to excess $\mathrm{NH}_{4}-\mathrm{N}$ cause changes in several metabolic reactions, inducing an increase in the content of reactive oxygen species, $\mathrm{O}_{2}$ and $\mathrm{H}_{2} \mathrm{O}_{2}$, which can cause oxidative peroxidation, reducing the levels of chlorophyll a and b (Jampeetong et al. 2012), and as a result of these reactions, the leaves had lower index of green color (Li et al. 2014, Prado 2008).

The combination of $\mathrm{NO}_{3}-\mathrm{N}$ and $\mathrm{NH}_{4}-\mathrm{N}$ attenuates the ammonium toxicity in many species (Britto and Kronzucker 2002). The orchids in this study grew better in the treatments with balance 

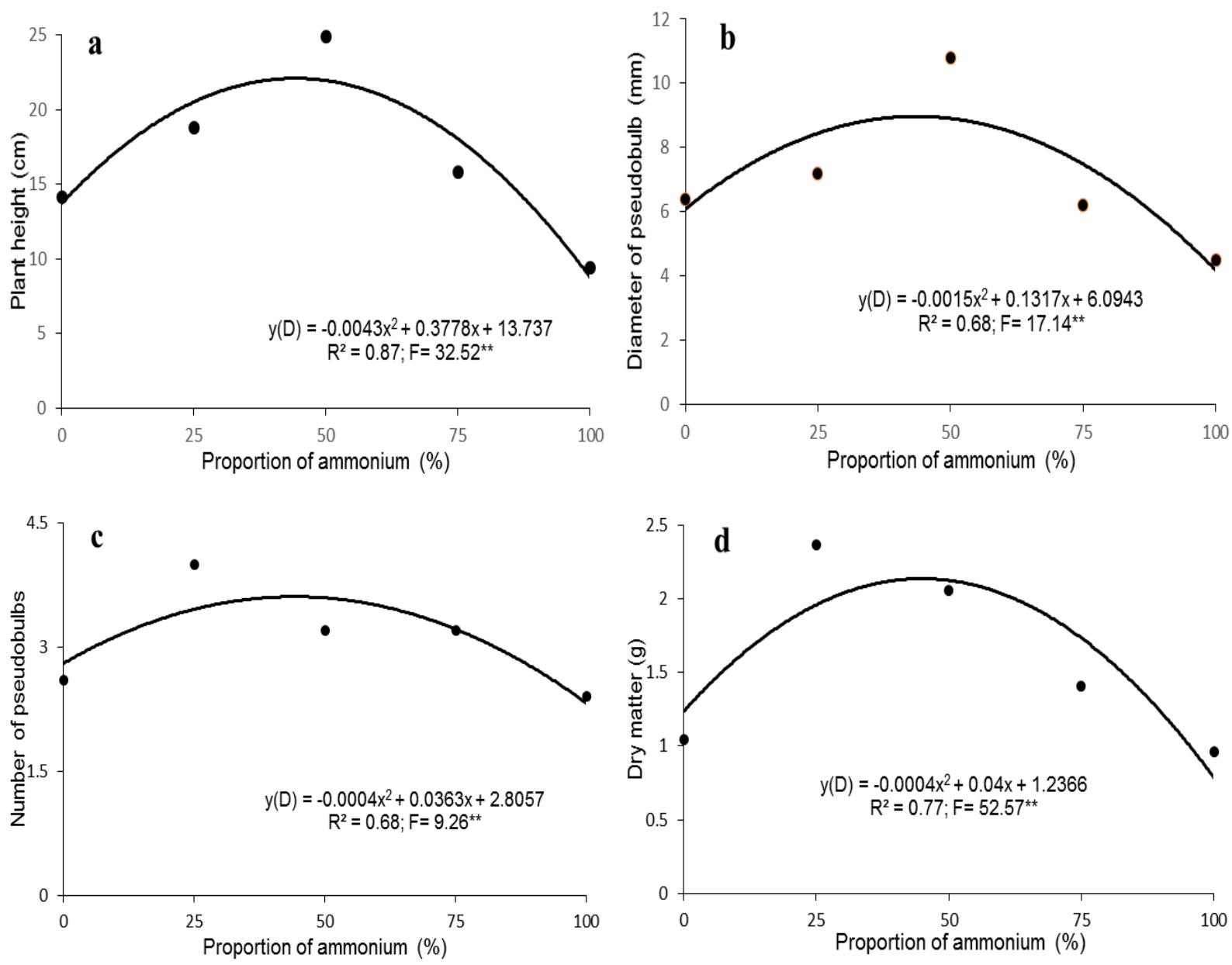

Figure 4 - Plant height (a), diameter of pseudobulb (b), number of pseudobulbs (c), and total dry matter (d) of Dendrobium 'Valentine' as a function of increasing proportions of ammonium (\%) in relation to nitrate, after 12 months from the beginning of the application of the treatments. $* * \mathrm{p}<0.01$ by the $\mathrm{F}$ test.

between these $\mathrm{N}$ sources, corroborating with the results obtained by Wang (2008) in Phalaenopsis and by Ruamrungsri et al. (2014) in Dendrobium.

The results indicated a tendency of greater accumulation of dry matter in the orchids, associated with a decrease in $\mathrm{NH}_{4}^{+}$concentration in the solution, similar to the results of studies with other cultivated plants (Warren and Adams 2002, Rothstein and Cregg 2005, Hachiya et al. 2007) which showed better plant growth in $\mathrm{NO}_{3}-\mathrm{N}$ and $\mathrm{NH}_{4}-\mathrm{N}$ mixtures. According to Bijlsma et al. (2000), the simultaneous assimilation of $\mathrm{NO}_{3}^{-}$and $\mathrm{NH}_{4}^{+}$by the roots has a better cost-benefit ratio than the assimilation of a single source of $\mathrm{N}$, that is, greater assimilation of $\mathrm{N}$ at a lower cost of $\mathrm{C}$ per mole of absorbed $\mathrm{N}$.

According to Liu et al. (2009), the higher biomass production capacity serves as an indicator to evaluate the ability of carbohydrate synthesis. The roots of plants fertilized with $\mathrm{NH}_{4}^{+}$alone have high $\mathrm{C}$ skeleton demands for ammonium assimilation (Arnozis et al. 1988) and high $\mathrm{O}_{2}$ consumption (Matsumoto and Tamura 1981), resulting in low sugar concentration in the roots and lower plant growth.

The negative effect of ammonium on plant growth variables, especially plant width and stem diameter of Phalaenopsis Golden Peoker, were 
similar to the results found with Phalaenopsis Blume x Taisuco Kochdian (Wang 2008), Eustoma grandiflorum (Mendoza-Villarreal et al. 2015) and Solanum lycopersicum (Borgognone et al. 2013).

This damage to orchid growth in response to $\mathrm{NH}_{4}-\mathrm{N}$ application as the exclusive source of $\mathrm{N}$ has been attributed mainly to the toxic effects of free ammonium (Ivanova and Staden 2009) which leads to an excess of cationic charge absorption, which must be balanced by an increase in $\mathrm{H}^{+}$efflux (Hachiya et al. 2012; Smith and Raven 1979). Therefore, for maximum growth and adequate nutrition of orchids, the nutrient solution should have a maximum of $40 \%$ and $50 \%$ ammonium for Phalaenopsis Golden Peoker and Dendrobium Valentine, respectively.

\section{ACKNOWLEDGMENTS}

We thank the Coordenação de Aperfeiçoamento de Pessoal de Nível Superior (C) for the scholarship granted the first author to carry out the master's degree course.

\section{REFERENCES}

ARNOZIS PA, NELEMANS JA AND FINDENEGG GR 1988. Phosphoenolpyruvate carboxylase activity in plants grown with either NO3- or NH4+ as inorganic nitrogen source. J Plant Physiol 132: 23-27.

BARBOSA JC AND MALDONADO JW. 2014. AgroEstat System for statistical analysis of agronomic trials - version 1.1.0.711. 2014. Jaboticabal: Faculty of Agrarian and Veterinary Sciences, UNESP.

BATAGLIA OC, FURLANI AMC, TEIXEIRA JPF, FURLANI PR AND GALLO JR. 1983. Methods of chemical analysis of plants. Campinas: Instituto Agronômico de Campinas, 48 p. (Technical Bulletin, 78).

BIJLSMA RJ, LAMBERS H AND KOOIJMAN SALM. 2000. A dynamic whole-plant model of integrated metabolism of nitrogen and carbon. 1. Comparative ecological implications of ammonium-nitrate interactions. Plant Soil 220: 49-69.

BITTSÁNSZKY A, PILINSZK K, GYULAI G AND KOMIVES T. 2015. Over coming ammonium toxicity. Plant Sci 231: 184-190.

BORGOGNONE D, COLLA G, ROUPHAEL Y, CARDARELLI M, REA E AND SCHWARZ D. 2013.
Effect of nitrogen form and nutrient solution $\mathrm{pH}$ on growth and mineral composition of self-grafted and grafted tomatoes. Sci Hortic 149: 61-69.

BRITTO DT AND KRONZUCKER HJ. 2002. $\mathrm{NH}_{4}^{+}$toxicity in higher plants: a critical review, J Plant Physiol 159: 567584.

CRUZ C, DOMÍNGUEZ-VALDIVIA MD, APARICIOTEJO PM, LAMSFUS C, BIO A, MARTINS-LOUÇÃO MA AND MORAN JF. 2011. Intra-specific variation in pea responses to ammonium nutrition leads to different degrees of tolerance. Environ Exp Bot 70: 233-243.

DIONISIO-SESE ML AND TOBITA S. 1998. Antioxidant responses of rice seedlings to salinity stress. Plant Sci 135 : $1-9$.

ESTEBAN R, ARIZ I, CRUZ C AND MORAN JF. 2016. Review: Mechanisms of ammonium toxicity and the quest for tolerance. Plant Sci 248: 92-101.

HACHIYA T, TERASHIMA I AND NOGUCHI K. 2007. Increase in respiratory cost at high growth temperature is attributed to high protein turnover cost in Petunia $\mathrm{x}$ hybrida petals. Plant Cell Environ 30: 1269-1283.

HACHIYAT, WATANABE CK, FUJIMOTO M, ISHIKAWA T, TAKAHARA K, KAWAI-YAMADA M AND NOGUCHI K. 2012. Nitrate addition alleviates ammonium toxicity without lessening ammonium accumulation, organic acid depletion and inorganic cation depletion in Arabidopsis thaliana shoots. Plant Cell Physiol 53: 577-591.

HESS DC, LU W, RABINOWITZ JD AND BOTSTEIN D. 2006. Ammonium toxicity and potassium limitation in yeast. PLOS Biology 4: 351-355.

HEW CS AND YONG JW. 2004. Mineral nutrition, p. 129167. In: Hew CS and Yong JW (Eds), The physiology of tropical orchids in relation to the industry. World Scientific Publishing Co Inc.

HOOPEN F, CUIN TA, PEDAS P, HEGELUND JN, SHABALA S, SCHJOERRING JK AND JAHN TP. 2010. Competition between uptake of ammonium and potassium in barley and Arabidopsis roots: molecular mechanisms and physiological consequences. J Exp Bot 61: 2303-2315.

HUANG L, LU Y, GAO X, DU G, MA X, LIU M, GUO J AND CHEN Y. 2013. Ammonium-induced oxidative stress on plant growth and antioxidative response of duckweed (Lemna minor L.) Ecol Eng 58: 355-362.

IVANOVA M AND STADEN JV. 2009. Nitrogen source, concentration, and $\mathrm{NH}_{4}^{+}: \mathrm{NO}_{3}^{-}$ratio influence shoot regeneration and hyperhydricity in tissue cultured Aloe polyphylla. Plant Cell Tiss Org 99: 167-174.

JAMPEETONG A, BRIX H AND KANTAWANICHKUL S. 2012. Effects of inorganic nitrogen forms on growth, morphology, nitrogen uptake capacity and nutrient allocation of four tropical aquatic macrophytes (Salvinia cucullata, Ipomoea aquatica, Cyperus involucratus and Vetiveria zizanioides). Aquat Bot 97: 10-16. 
LI B, LI G, KRONZUCKER HJ, BALUSKA F AND SHI W. 2014. Ammonium stress in Arabidopsis: signaling, genetic loci, and physiological targets. Trends Plant Sci 19: 107114.

LIU XJ, XU ZS AND ZHANG NN. 2009. Effects of different culture media on the growth of Indian sandalwood (Santalum album L.) seedlings in Zhanjiang, Guangdong, southern China. Forestry Studies in China 11: 132-138.

MANTOVANI C, PRADO RM AND PIVETTA KFL. 2015. Foliar diagnosis in Phalaenopsis orchid plants subjected to application of nitrogen. Afri J Agric Res 53: 4906-4912.

MATSUMOTO H AND TAMURA K. 1981. Respiratory stress in cucumber roots treated with ammonium or nitrate nitrogen. Plant Soil 60: 195-204.

MENDOZA-VILLARREAL R, VALDEZ-AGUILAR LA, SANDOVAL-RANGEL A, ROBLEDO-TORRES V AND BENAVIDES-MENDOZA A. 2015. Tolerance of Lisianthus to high ammonium levels in rockwool culture. J Plant Nut 38: 73-82.

PRADO RM. 2008. Nitrogen. In: Prado RM (Ed), Plant nutrition. UNESP, Jaboticabal, p. 83-120.

ROTHSTEIN DE AND CREGG BM. 2005. Effects of nitrogen form on nutrient uptake and physiology of Fraser fir (Abies fraseri). Forest Ecol Manag 219: 69-80.

RUAMRUNGSRI S, KHUANKAEW T, OHYAMA T AND SATO T. 2014. Nitrogen sources and its uptake in Dendrobium Orchid by $15 \mathrm{~N}$ tracer study. In International Symposium on Orchids and Ornamental Plants 1025, p. 207-211.
SARASKETA A, GONZÁLEZ-MORO MB, GONZÁLEZMURUACAND MARINO D. 2014. Exploring ammonium tolerance in a large panel of Arabidopsis thaliana natural accessions. J Exp Bot 65: 6023-6033.

SARRUGE JR. 1975. Nutrition solutions. Summa Phytopathol 1: 231-233.

SIDDIQI MY AND GLASS ADM. 1981. Utilization index: a modified approach to the estimation and comparison of nutrient utilization efficiency in plants. J Plant Nut 4: 289302.

SIDDIQI MY, MALHOTRA B, MIN X AND GLASS ADM. 2002. Effects of ammonium and inorganic carbon enrichment on growth and yield of a hydroponic tomato crop. J Plant Nut Soil Sc 165: 191-197.

SMITH FA AND RAVEN JA. 1979. Intracellular pH and its regulation. Annu Rev Plant Phys 30: 289-311.

SWIADER JM, CHYAN Y AND FREIJI FG. 1994. Genotypic differences in nitrate uptake and utilization efficiency in pumpkin hybrids. J Plant Nutr 17: 1687-1699.

WANG YT. 2008. High NO3-N to NH4-N ratios promote growth and flowering of a hybrid Phalaenopsis grown in two root substrates. Hortscience 43: 350-353.

WANG YT AND CHANG YCA. 2017. Effects of Nitrogen and the Various Forms of Nitrogen on Phalaenopsis Orchid-A Review. HortTechnology 27: 144-149.

WARREN CR AND ADAMS MA. 2002. Possible causes of slow growth of nitrate-supplied Pinus pinaster. Can J Forest Res 32: 569-580. 